Print ISSN: 2233-4165 / Online ISSN: 2233-5382

doi:http://dx.doi.org/10.13106/ijidb.2018.vol9.no10.73.

\title{
The Economic Impact of Government Purchases on the Price Volatility of Korean Dried Red Pepper*
}

\author{
건고추 정부수매의 가격안정화효과에 대한 사후영향평가분석 \\ $\mathrm{Su}-$ Yeon Park(박수연) $)^{* *}$, In-Seck Kim(김인석) $)^{* * *}$
}

Received: August 14, 2018. Revised: August 30, 2018. Accepted: September 15, 2018.

\begin{abstract}
Purpose - Unstable vegetable prices have been one of the major concerns in Korean agricultural and food marketing system. The Korean government has implemented a number of policy instruments, including government purchasing programs in order to alleviate fluctuations in vegetable prices. The economic impact of policy instruments has been assessed based on the average monthly price change rate before and after the implementation of the policy. However, this approach failed to provide a net impact of policy measures on price stabilization in the vegetable markets, as policy impacts could not be successfully distinguished from other effects on price changes in the vegetable market. The purpose of this study is to evaluate the net impact of the government purchasing program on the price volatility of dried red pepper which is considered one of the major vegetables in Korea.

Research design, data, and methodology - This study develops a monthly dynamic partial equilibrium model of Korean dried red pepper market. Behavioral equations in the model were estimated by OLS and synthetic method based on the annual and monthly time series data from 1993 to 2015. The model is first simulated to yield actual dried red pepper market conditions in 2015 as a baseline and then compared it to the scenario assuming that there were no government purchases of dried red pepper in 2015.

Results - According to the ex-post scenario analysis using the developed model, without the government procurements in 2015, the average monthly price change rate and the value of coefficient of variation of dried red pepper in 2015 would be respectably 7.9 percent and 0.10 . It is relatively higher than the actual average monthly price change rate and the value of coefficient of variation of dried red pepper in 2015 which were respectively 1.7 percent and 0.06 .

Conclusions - The ex-post simulation results in this study shows that if there were no government purchases of dried red pepper in 2015, the dried red pepper market would have had much higher volatile price movements. The results of this study would provide useful information for future price stabilization policy of vegetable markets in Korea.
\end{abstract}

Keywards: price volatility, dried red pepper, ex-post analysis, dynamic partial equilibrium model

JEL Classifications: C51, C53, Q1, Q11, Q18

\section{1. 서론}

농산물의 높은 가격 변동성은 농가소득의 불안정성을 야기 하는 요인으로 농산물 유통의 대표적인 문제 중의 하나로 인 식되어 왔다. 이러한 농산물 가격의 급등락은 농가소득뿐만 아

* This paper was modified and developed from the MS thesis of the first author.

** First Author, Researcher, Korea Rural Economic Institute, Korea.

*** Corresponding Author, Associate Professor, Department of Agricultural Economics, Chonnam National University, Korea. Tel:+82-62-530-2171, E-mail: i.kim@jnu.ac.kr
니라 체감 소비자 물가에 부정적인 영향을 주어 농업부분의 문제를 넘어 전체 경제에 영향을 주는 주요한 사회적 이슈가 되었다. 반복되는 농산물 가격의 폭락과 폭등 문제에 대한 종 합적이고 성공적인 대응책 제시에 어려움을 보여 왔던 정책당 국은 농산물 가격 불안정성을 완화하기 위하여 농산물 유통 개선을 주요한 국정과제로 선정하여 2013년 5월 27일 농산물 유통구조개선 종합 대책을 발표하였다. "2013년 $5 \cdot 27$ 농산물 유통구조개선 종합대책”은 수급 관리 체계화를 통한 가격 안 정화를 주요 목표로 설정하고, 이를 달성하기 위하여 농업 관 측 고도화, 주요 품목 수급 조절 매뉴얼 운영, 계약재배 확대, 국내산 수매 비축 확대 등의 세부 정책을 제시하고 지속적으 로 시행 중에 있다. 
현재 정부에서는 이렇게 추진된 수급 체계화 정책의 성과를 가격 변동성이 심한 5 대 채소(건고추, 배추, 무, 마늘, 양파)를 대상으로 정책 추진 전후의 월평균 전월대비 가격변동률로 평 가하고 있다. 실제로 수급관리 체계화 정책 전후의 5대 채소 전월대비 평균 가격 변동률은 2012년 $19.0 \%, 2013$ 년 $12.9 \%$, 2014년 9.8\%로 2013년 5월 수급관리 체계화 정책 이후에 가 격 변동률이 낮아지고 있음을 볼 수 있다. 그러나 이러한 정책 추진 전후의 단순 평균 가격 변동률 변화는 정부의 수급체계 화 정책 효과뿐만 아니라 여러 요소들의 영향을 포함한 종합 적인 효과의 결과로서, 정부 정책 추진에 의한 순효과(net effect)를 측정하는 데 한계가 있다.

본 연구는 정부가 가격 변동성을 집중적으로 관리하고 있는 5 대 채소 중 건고추를 대상으로, 대표적인 수급체계화 정책수 단 중 하나인 정부 수매 비축사업이 단기 건고추 시장에 미치 는 영향과 궁극적으로 건고추 가격 변동률에 미치는 순효과를 정량적으로 사후평가하고자 한다.

이를 위하여 본 연구는 기존 선행연구들의 한계점을 보완할 수 있는 월간 동태부분균형모형(monthly dynamic partial equilibrium model)을 개발하여 "2013년 5-27 농산물 유통구조 개선 종합대책" 이후에 이루어졌던 건고추 수매 중 가장 최근 에 이루어진 2015년 10월, 11월의 건고추 수매 비축이 2015 년 10월부터 2016년 7월까지 10개월 동안의 건고추 시장과 2015 연산연도(2015년 8월 2016년 7월) 건고추 가격 변동률 에 미친 영향을 분석하였다.

건고추는 2015년 기준 생산액이 8,806억 원으로 전체 농업 총 생산액(445,188억 원)에서 차지하는 비중은 $2.0 \%$ 로 그리 크지 않지만, 조미채소류 생산액(19,665억 원)에서 차지하는 비중은 $44.8 \%$ 로 가장 높은 우리나라의 대표적인 노지채소 중 하나이다. 건고추 산업은 농촌인구 고령화와 수입증가로 재배 면적 및 자급률이 축소되고 있는 추세이지만, 여전히 많은 농 가에서 재배하고 있는 주요 소득 작목 중의 하나이다.

본 연구의 구성은 다음과 같다. 제 2장에서는 선행연구를 정리하고, 제 3장에서는 분석모형과 자료 그리고 분석모형을 이용한 사후영향평가 절차에 대하여 설명하였다. 제 4장에서 는 분석 결과를 제시하고, 마지막으로 제5장에서는 분석 결과 를 요약하고 시사점을 도출하였다.

\section{2. 선행연구 고찰}

\section{1. 변동성의 측정}

환율, 국제유가, 이자율과 같은 거시경제 변수 및 주식시장 의 변동성(volatility)은 경제정책 당국을 포함한 모든 시장 참여 자들의 관심사항으로서, 거시경제학의 주요 주제로 다루어져왔 다(Hong, 2016; Kim \& Yi, 2016). 거시경제 변수 및 주식시장 의 변동성의 크기, 원인 및 영향은 다양한 방법으로 측정되어 왔지만 해당 확률변수의 조건부 분산을 모형화한 $\mathrm{GARCH}$ 모 형, $\mathrm{GARCH}$ 모형의 확장 모형 등이 폭 넓게 이용되었다(Kim, 2013; Sahadudheen, 2015; Rahmi, Azma, Muttaqin, Jazil, \& Rahman, 2016; Siddiqui \& Erum, 2016).

변동성에 대한 이러한 접근방법은 일반 경제 변수 혹은 주 식시장뿐만 아니라 외부환경 변화에 따른 농산물 가격 변동성 측정에도 주로 적용되었다(Trujillo-Barrera, Mallory, \& Garcia, 2012; Karali \& Power, 2013; Lama, Jha, Paul, \& Gurang, 2015; Jati \&
Premaratne, 2017; Saghaian, Nemati, Walters, \& Chen, 2018).

그러나 이러한 분석방법은 특정 시기나 정책 시행 전·후에 분 산의 변동 폭을 직접적으로 비교하기보다는 가격의 분산구조가 달라지는 것을 검증하는 데 초점이 맞추어져 있다. 이와 달리 평 균 대비 표준편차의 비중으로 정의되는 변이계수(coefficient of variation) 접근 방법은 변동성을 보다 직접적으로 측정·비교할 수 있고 복잡한 모형설정과 추정과정 없이 쉽게 계산할 수 있어 농 산물가격, 농업소득, 수확량 등의 변동성 측정에 많이 이용되고 있다(Huang \& Huang, 2012; Su \& Cook, 2015; Key, Prager, \& Burns, 2018).

한편, Jin and $\mathrm{Kim}(2012)$ 은 일반적인 변이계수를 활용한 가 격변동성 측정의 문제점들을 지적하고 이를 보완하기 위한 방 법으로 구조변화(structural break)를 고려한 조정된 변이계수 추정방법을 제시하였다. 이러한 접근방법은 일반적인 변이계수 를 활용한 가격변동성 측정의 한계점을 보완하여 측정결과의 엄밀성을 제고했다는 데 의의가 있지만 여전히 정부정책 이외 의 다른 가격 변동 요인에 대한 적절한 설명이 어려워 정책의 순효과를 계측하는 데 제약이 있다.

\section{2. 부분균형 모형}

새로운 정부 정책 도입 혹은 정책 변화와 같은 외부환경 변 화가 농산물 시장에 미치는 영향을 효과적으로 분석하기 위해 서는 정책 도입 혹은 변화 전·후의 단순 비교가 아닌 동일시점 에서 정책의 유·무에 따라 달라진 시장상황을 비교해야 한다. 이를 위해서는 정책변수 혹은 외부환경 변화와 관련된 변수뿐 만 아니라 농산물 시장에 영향을 미치는 다른 주요한 변수들 의 영향을 분석하고 또한 궁극적으로 정책변수 이외의 변수들 의 영향을 통제할 수 있는 분석의 틀이 필요하다.

이러한 측면에서 농업정책 분석 관련 많은 선행연구들이 농 산물시장의 수급과 가격결정구조를 묘사한 일반균형(general equilibrium) 혹은 부분균형(partial equilibrium) 모형을 이용하 고 있다. 특히, 부분균형 모형은 주어진 경제 내에서의 특정 농산물시장만을 고려 대상으로 취급함으로써 다른 시장과의 연관 관계를 통한 파급 효과 및 경제 내의 총량적 효과를 분 석하는 데는 한계가 있지만, 일반균형 모형에 비해 해당 농산물 시장의 수급 구조 및 다양한 정부정책들을 좀 더 자세히 묘사 한다는 측면에서 농업정책 평가에 많이 이용되고 있다(Mcphail \& Babcock, 2012; Hoang \& Meyers, 2015; Thompson, Gerlt, Campbell, Kueppers, Lu, \& Snyder, 2017).

이러한 이유로 국내 5대 채소시장 관련 정책분석 및 외부환 경변화 영향분석에 부분균형 모형을 이용한 선행연구가 다수 존재한다. 그러나 대부분의 연구가 가상의 기후변화가 배추시 장에 미치는 영향을 분석한 연구와 같이 현재시점을 기준으로 일어나지 않은 미래상황에서의 변화와 그에 따른 영향을 분석 하는 사전분석(ex-ante analysis)으로, 과거정책의 순효과를 분 석하는 사후분석(ex-post analysis)과는 차이가 있다.

여기에 더하여 부분균형모형 접근방법을 이용한 5대 채소 관련 대부분의 선행연구들은 연간 자료를 이용한 연간모형이 거나 작형별 자료를 이용한 분기모형으로서 단기가격 불안정 이 가장 큰 관심사인 채소부분의 정부정책변화에 따른 월간시 장의 변화, 특히 월간 가격 변동률 계측이 어렵다는 한계점을 가지고 있다.

부분균형모형을 이용한 기존의 5 대 채소관련 연구들의 또 다른 특징은 균형대체모형(equilibrium displacement model)에 
바탕한 비교정태분석모형이라는 점이다. 시간의 흐름에 따른 경제 변수들의 움짐임 혹은 경제 변수들간의 단기와 장기에서 의 인과관계 및 관계성의 크기를 측정하는 동태분석(Lee \& Zhao, 2014; Lee \& Brahmasrene, 2018)과 달리 비교정태분석 은 정부 정책변화와 같은 외부환경 변화가 특정시점에 미치는 영향을 측정하는 분석이다. 이러한 측면에서 5 대 채소관련 기 존 선행연구들은 정부수매와 같은 정부정책의 영향이 시장에 서 시간의 흐름에 따라 어떻게 조정되는지에 대한 동태적 분 석이 어렵다는 한계점이 있다.

본 연구는 월간 자료를 이용한 동태부분균형모형을 통하여 정부정책이 가격변동률에 미치는 영향을 사후분석한다는 점에 서 기존의 5 대채 소시장관련 선행연구와의 차별성을 가진다.

\section{3. 연구방법론}

\section{1. 분석모형}

본 연구의 모형은 <Figure $1>$ 에서 보는 바와 같이 생산비용 을 제외한 건고추와 관련된 모든 주요변수를 내생변수로 취급 하여 건고추 생산자의 생산결정에서 도매단계 소비까지의 전 과정을 모형화한 월간 동태부분균형모형(monthly dynamic partial equilibrium model)이다. 모형 내의 개별 방정식은 연간 변수인 재배면적과 단수 그리고 재배면적과 단수의 곱으로 얻 어지는 생산량과 월간 변수인 재고량, 수입량, 수출량, 도매단 계 소비량, 도매시장 가격 그리고 도매단계 가격과 농가 단계 가격을 연결하는 가격 연결 방정식으로 구성되어 있다.

월간 도매시장가격은, 가격을 공급량(균형조건 하에서 수요 량으로 취급)의 함수로 설정하는 역수요함수를 통해 직접 추 정하는 일반적인 축차모형(recursive model)하의 가격결정식을 이용하는 기존의 5 대채소관련 선행연구와는 달리 매월 월 생 산량, 월초 재고, 수입량의 합인 도매단계 공급량과 도매단계 소비량, 수출량, 월말재고의 합인 도매단계 수요량이 일치하는 12 개의 항등식을 통해서 구해지는 연립방정식(simultaneous equation system)의 형태로 도출하였다. 이를 위하여 재고, 수 입, 소비를 각각 12 개의 함수로 월별로 설정하여 추정하였다.

축차형 가격결정방식이 아닌 연립방정식 형태를 이용하는 이유는 축차형에서 발생하는 파라미터의 편의(bias)를 막을 수 있어 통계적으로 일관성이 있을 뿐만 아니라 월간 건고추시장 의 가격 결정방식을 좀 더 현실적으로 묘사하여 보다 구체적 인 정책분석이 가능하기 때문이다.

농산물의 경우 단기적으로는 가격 변화에 따라 농산물 수급 량이 반응하기보다는 주어진 공급량에 따라 가격이 반응한다 는 가정 하에서 분기 혹은 월간 농산물 수급 모형은 역수요함 수 형태의 가격 결정 방식이 많이 이용된다. 하지만 건고추와 같이 일정 기간 저장이 가능하고, 가격 변화에 정부와 민간 유 통업자들이 저장된 재고물량과 수입량을 조절 가능한 경우는 총수요(소비량, 기말재고량, 수출량)와 총공급(생산량, 기초재고 량, 수입량)의 요소들을 일차적으로 시장가격의 함수로 추정한 후 최종적으로 총수요와 총공급의 항등식을 통하여 시장균형 가격을 도출해내는 연립방정식형태의 모형이 좀 더 현실에 부 합한 접근방법이라 할 수 있다.

분석모형의 또 다른 특징은 동태모형이라는 것이다. 동태적 특징에 대한 설명은 뒤에서 나올 분석방법에서 서술되어 있다 (<Figure 1>).

모형 내의 개별방정식들에 대한 구체적인 설명은 다음과 같다.

\subsection{1. 재배면적 함수}

건고추 재배면적 $\left(A C R_{t}^{i}\right)$ 은 전국 재배면적을 주산지인 전라남 도, 전라북도, 경상북도와 충청북도, 그리고 기타지역 재배면적으 로 구분하여 전기 재배면적 $\left(A C R_{t-1}^{i}\right)$, 농가판매가격과 생산비용 비율의 과거 3 년 가중평균에 과거 3 년 가중평균 단수의 곱을 통 해 얻은 건고추 예상 순수익 $\left(N E T R P_{t}^{i}\right)$, 대체 작물인 콩의 예상 순수익 $\left(N E R T S_{t}^{i}\right)$ 의 함수로 설정하였다. 여기서, i와 t는 지역과 연도를 나타낸다.

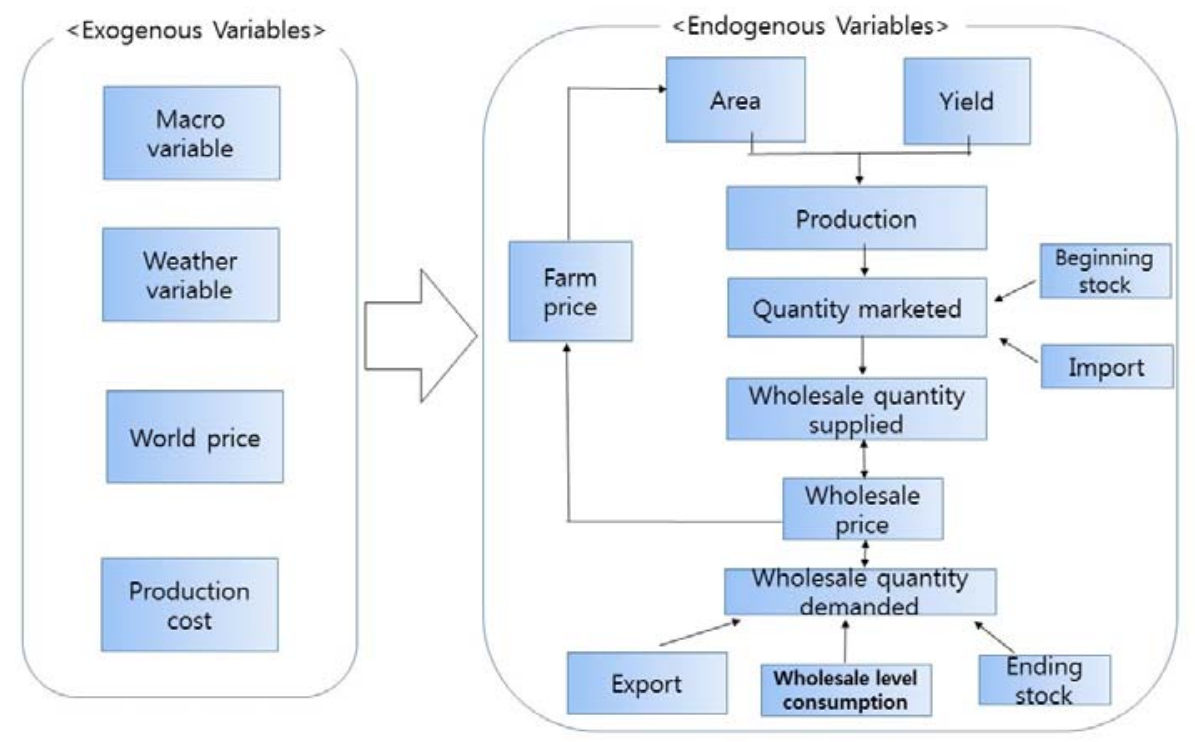

<Figure 1> Korean Dried Red Pepper Market Flow Diagram 


$$
A C R_{t}^{i}=f\left(A C R_{t-1}^{i}, N E T R P_{t}^{i}, N E T R S_{t}^{i}\right)
$$

\subsection{2. 단수 함수}

건고추의 단수 $\left(Y D_{t}^{i}\right)$ 는 7월 9월의 기상변수에 의해 크게 영 향을 받는다. 이에 본 연구는 건고추 단수를 재배면적 함수와 마찬가지로 주산지를 구분하여 7 9월 평균기온(AVTEMP $\left.{ }_{t}^{i}\right)$, 7 9월 일조시간 $\left(S U N_{t}^{i}\right), 7 \sim 9$ 월 강수량 $\left(R A I N_{t}^{i}\right)$ 의 함수로 설정 하였다.

$$
Y D_{t}^{i}=f\left(A V T E M P_{t}^{i}, S U N_{t}^{i}, R A I N_{t}^{i}\right)
$$

\subsection{3. 연생산량과 월생산량}

먼저 지역별 생산량 $\left(Q_{t}^{i}\right)$ 은 앞에서 추정한 지역별 재배면적 과 단수의 곱으로 산출하였으며 전국 생산량 $\left(Q_{t}\right)$ 은 지역별 생 산량 합으로 도출하였다. 이렇게 도출된 연생산량을 월간 모형 에 사용하기 위해서는 월생산량으로 변환이 필요하다. 건고추 의 경우 연간 1 회 생산되어 저장 출하되는 상품이므로 시장의 특성을 반영하기 위해 월생산량 $\left(Q_{t}^{j}\right)$ 은 8 월에 연간생산량이 전 부 생산되고 나머지 9 월에서 이듬해 7 월까지의 생산량은 0 으 로 처리하였다. 여기서, $j$ 는 월을 나타낸다.

$$
Q_{t}=\sum_{i} Q_{t}^{i}=\sum_{i} A C R_{t}^{i}{ }^{*} Y D_{t}^{i}
$$

\subsection{4. 월말재고수요 함수}

1년 1 기작 생산 농산물의 재고수요에는 예방적 수요, 투기 적 수요, 거래적 수요가 있다. 예방적 수요는 월말재고수요 $\left(E S T_{t}^{j}\right)$ 의 상수항, 거래적 수요는 전월 월말재고수요를 나타내는 월초재고량 $\left(B S T_{t}^{j}\right)$, 투기적 수요는 실질도매시장가격 $\left(\frac{W P_{t}^{j}}{C P I_{t}^{j}}\right)$ 으 로 설정하였다. 8월의 경우 햇건고추 물량이 나오기 때문에 햇물 량의 영향을 나타내기 위하여 생산량 $\left(Q_{t}\right)$ 을 추가하여 설정하였다.

$$
E S T_{t}^{j}=f\left(B S T_{t}^{j}, \frac{W P_{t}^{j}}{C P I_{t}^{j}}, Q_{t}\right)
$$

\subsection{5. 수입수요 함수}

건고추의 월별 수입수요 $\left(M_{t}^{j}\right)$ 는 건고추의 전월 실질도매시 장가격 $\left(\frac{W P_{t}^{j-1}}{C P I_{t}^{j-1}}\right)$, 건고추의 전월 실질수입단가 $\left(\frac{I M P_{t}^{j-1}}{C P I_{t}^{j-1}}\right)$, 월 초재고량 $\left(B T S_{t}^{j}\right)$ 의 함수로 추정하였다. 8월 수입수요함수는 전월 실질도매시장가격이 아닌 전기의 실질도매시장가격 $\left(\frac{W P_{t-1}^{j}}{C P t_{t-1}^{j}}\right)$ 으로 추정하였다. 이는 앞서 설명한 재고수요와 마 찬가지로 햇물량이 본격적으로 출하되는 8 월에는 새로운 가격 이 생성됨으로써, 전월가격보다 전기가격에 더 반응한다고 볼 수 있어 전기의 함수로 설정하였다.

$$
M_{t}^{j}=f\left(\frac{W P_{i}^{j-1}}{C P I_{t}^{j-1}}, \frac{I M P_{t}^{j-1}}{C P I_{t}^{j-1}}, B T S_{t}^{j}, \frac{W P_{t-1}^{j}}{C P I_{t-1}^{j}}\right)
$$

\subsection{6. 도매단계 소비 함수}

도매단계의 소비는 소비자 수요에서 파생되는 파생수요로서 소매업자의 구매행위를 나타낸다. 파생수요함수인 도매단계 소 비함수를 적절히 추정하기 위해서는 소매단계 가격과 도매단계 가격 그리고 유통비용을 변수로 하여 추정이 이루어져야 하지 만, 소매단계 가격과 유통비용의 월별자료제약으로 본 연구에 서는 도매단계 소비함수 $\left(D_{t}^{j}\right)$ 를 건고추 실질 도매가격 $\left(\frac{W P_{t}^{j}}{C P I_{t}^{j}}\right)$ 과 추세변수 $(T R E N D)$ 만을 고려하여 설정하였다.

$$
D_{t}^{j}=\mathrm{f}\left(\frac{W P_{t}^{j}}{C P I_{t}^{j}}, T R E N D\right)
$$

\subsection{7. 도매시장균형가격(시장청산가격)}

본 연구에서는 앞에서 언급한 바와 같이, 균형가격을 축차 모형에서의 역수요함수를 이용한 직접 추정이 아닌 연립방정 식 체계에서 수요와 공급을 일치시키는 반복계산(iteration)을 통해 도출하였다. 반복계산을 통한 균형가격 도출은 대표적 농 업정책 연구기관인 미국 FAPRI(Food and Agricultural Policy Research Institute)에서 개발한 방법으로 다양한 FAPRI 농업 부분균형모형에서 이용되고 있다(Meyers, Westhoff, Fabiosa, \& Hayes, 2010; Thompson, Johansson, Meyer, \& Whistance, 2018).

반복계산은 식 $(7)$ 에서 보는 바와 같이, 월생산량 $\left(Q_{t}^{j}\right)$, 월초재 고량 $\left(B T S_{t}^{j}\right)$, 월수입량 $\left(M_{t}^{j}\right)$ 의 합인 총공급 $\left(T S_{t}^{j}\right)$ 과 월소비량 $\left(D_{t}^{j}\right)$, 월말재고량 $\left(E S T_{t}^{j}\right)$, 월수출량 $\left(X_{t}^{j}\right)$ 의 합인 총수요 $\left(T D_{t}^{j}\right)$ 가 임의로 주어진 초기의 가격 $\left(W P_{t, k-1}^{j}\right)$ 에 의해 결정된 후, 만일 초 과 수요가 존재하면 균형 조정계수(ס)를 통해서 가격을 상승시키 고, 초과 공급이 있으면 가격을 하락시키는 조정과정을 통해서 수요와 공급이 일치하는 균형가격 $\left(W P_{t, k}^{j}=W P_{t, k-1}^{j}\right)$ 에 도달할 때 까지 모형 내의 가격 함수인 행태방정식들을 반복시켜서 수렴하 는 과정이다. 여기서, $k$ 는 모형이 수렴하기까지의 반복횟수로서 1 부터 무한대까지이고 $(k=1 \sim \infty)$, 균형 조정계수 $\delta$ 는 0 과 1 사이의 임의의 숫자이다 $(0<\delta<1)$. 이러한 반복계산을 통해 수렴되는 가격은 시장에서 수요와 공급이 일치되는 시장청산가격 (market-clearing price)이라고 할 수 있다.

$$
\begin{aligned}
& W P_{t, k}^{j}=W P_{t, k-1}^{j}-\delta\left(T S_{t}^{j}-T D_{t}^{j}\right), \\
& T S_{t}^{j}=Q_{t}^{j}+B T S_{t}^{j}+M_{t}^{j} \\
& T D_{t}^{j}=D_{t}^{j}+E S T_{t}^{j}+X_{t}^{j}
\end{aligned}
$$

\subsection{8. 가격 연결식}

가격 연결식은 농가판매가격과 도매시장가격과의 관계를 나 타내는 함수로서, 모형내의 시장청산가격인 월 도매시장가격의 산술평균인 연간 도매시장가격 $\left(W P_{t}\right)$ 이 연간 농가가격 $\left(F P_{t}\right)$ 에 영향을 미치는 구조로 설정되었다. 


$$
F P_{t}=f\left(W P_{t}\right), \quad W P_{t}=\sum_{j} \frac{W P_{t}^{j}}{12}
$$

\subsection{9. 월초재고량과 수출량}

월초재고량 $\left(B S T_{t}^{j}\right)$ 은 전월월말재고량 $\left(E S T_{t-1}^{j}\right)$ 의 이월량으 로서 전월월말재고량과 항등식의 관계에 있고 수출량의 경우 극히 소량으로 모형 내에서 외부환경 변화에 반응하지 않고 일정하다고 가정하였다.

\section{2. 분석자료}

건고추 월간동태부분균형모형 추정에 이용된 시계열 자료는 연간자료의 경우는 1993년부터 2015년, 월간자료의 경우는 2000년부터 2015년까지이다. 연간 자료인 지역별 재배면적, 단수, 생산비, 농가가격 자료는 통계청의 자료를 이용하였고, 단수추정에 이용된 기상자료의 경우는 기상청 국가기후자료센 터 자료를 이용하였다. 월간자료인 수출입 물량은 한국무역협 회, 월간 재고물량은 한국농촌경제연구원의 관측월보 자료를 이용하였다. 월간 도매단계 소비량 자료는 연간 소비량 자료에 도매시장 월별출하비중을 곱하여 도출하였다. 월간 도매시장가 격은 한국농수산식품유통공사의 화건 상품 자료를 이용하였고, 건고추 수입단가는 한국무역협회 자료를 이용하였다.

월간자료의 경우 생산자, 유통업자들의 의사결정과정을 현 실적으로 묘사하기 위하여 1월부터 12월까지의 회계연도가 아 닌 농산물이 수확되어 시장에 유통되는 연산연도(crop year)를 기준으로 정리하여 이용하였다. 건고추의 연산연도는 8월에서 익년 7월까지이다.

\section{3. 분석방법}

사후분석(ex-post analysis)은 현재 $(t)$ 를 기준으로 이미 실현 된 과거시점 $(t-i)$ 에 대한 분석으로서 본 연구에서는 모형 내 행태방정식들의 추정치와 잔차항을 통하여 묘사된 과거 시장 상황과, 정책 실현이 없었던 상황을 가정하여 도출한 시나리오 분석치의 비교를 통해서 이루어진다. 이때 과거 정책 실현의 결과인 실제 과거 수급 상황은 시나리오의 비교 대상이 돼서 벤치마크역할을 하는 기준전망치(Baseline)이다. 이러한 접근 방법은 2004년에 발효된 한·칠레 FTA가 한국농업에 미치는 영향을 한국농촌경제연구원의 한국농업시뮬레이션모형(KASMO) 를 이용하여 사후 평가한 연구방법과 유사하다.

사후분석의 절차를 설명하면 다음과 같다. 첫째, 사후분석 시 개별 행태방정식의 기준전망치 $\left(Y_{t-i}^{B}\right)$ 를 도출하는 것은 이 미 일어난 현실상황을 모형으로 다시 재현해내는 것인데, 이는 모형 내 개별 행태방정식들의 추정치 $\left(\widehat{Y_{t-i}^{B}}\right)$ 와 실제자료 $\left(Y_{t-i}^{B}\right)$ 와 추정치 $\left(\widehat{Y_{t-i}^{B}}\right)$ 의 차이인 잔차항 $\left(\widehat{U_{t-i}^{B}}\right)$ 의 합으로 도출된다.

$$
Y_{t-i}^{B}=\widehat{Y_{t-i}^{B}}+\widehat{U_{t-i}^{B}}
$$

둘째, 과거 정부정책이 없음을 가정하는 시나리오 분석치 $\left(Y_{t-i}^{S}\right)$ 는 분석대상이 되는 정책변수의 수치 변화 이외에는 기 준전망치 도출에 이용된 동일한 변수들의 추정치를 이용한 개 별 행태방정식들의 추정치 $\left(\widehat{Y_{t-i}^{S}}\right)$ 와 기준전망치와 동일한 잔차 항 $\left(\widehat{U_{t-i}^{S}}=\widehat{U_{t-i}^{B}}\right)$ 을 그대로 이용하여 도출한다.

$$
Y_{t-i}^{S}=\widehat{Y_{t-i}^{S}}+\widehat{U_{t-i}^{S}}
$$

마지막으로 사후영향평가의 결과는 시나리오와 베이스라인 의 차이로 구해진다.

$$
Y_{t-i}^{S}-Y_{t-i}^{B}=\widehat{Y_{t-i}^{S}}+\widehat{U_{t-i}^{S}}-\widehat{Y_{t-i}^{B}}-\widehat{U}_{t-i}^{B}=\widehat{Y_{t-i}^{S}}-\widehat{Y_{t-i}^{B}}
$$

위 식에서 유의할 부분은 시뮬레이션 과정에서 기준전망치 와 시나리오 분석치의 잔차항의 값이 같고, 기준전망치와 시나 리오 분석치의 차이는 단순히 정부정책과 관련된 변수 값의 차이일 뿐이라는 것이다.

베이스라인과 시나리오 값의 잔차항이 고정되어서 동일한 값을 가진다는 가정을 통한 사후분석은, 정부정책의 영향은 오 직 모형내의 설명 변수의 변화를 통해서만 반영되고, 잔차항으 로 설명되는 설명변수 이외의 다른 요소들은 정부정책 변화에 반응하지 않는다는 것을 의미한다. 이러한 접근방법은 정부정 책의 영향 분석에서, 구체적으로 묘사되지 않은 기타 변수들의 영향을 모형 내에서 효과적으로 통제함으로써 시나리오 분석 치와 기준전망치의 비교를 통해 정책 시행이 시장 수급과 가 격에 미치는 영향을 효과적으로 분석 가능하게 한다.

한편 식 (9), (10), (11)을 통해서 설명한 사후분석 방법은 과거시점 $(t-i)$ 에 일어난 정부정책이 동일시점인 $(t-i)$ 시점의 시장에 미치는 영향을 측정한 것이다. 즉 $(t-i)$ 시점에서 정 부정책의 유·무에 따른 시장균형의 변동 상황을 측정한 비교정 태분석이라고 할 수 있다. 그러나 정부정책의 영향은 지속성을 가진다. 예를 들어, 건고추 정부수매가 과거 $(t-i)$ 시점에서 실시되었다 하더라도 그 영향은 $(t-i)$ 시점에 그치는 것이 아 니라 시간의 흐름에 따라 그 영향이 변화하면서 어느 시점까 지 지속된다는 점이다. 이러한 동태적 시장 상황을 분석하기 위하여 본 연구는 $(t-(i-1))$ 시점부터 $t$ 시점까지의 개별 행 태방정식들의 기준전망치 $Y_{t-(i-1)}^{B},---, Y_{t}^{B}$, 시나리오 분석치 $Y_{t-(i-1)}^{S},---, Y_{t}^{S}$ 를 식 (9)와 식 (10)에서 $Y_{t-i}^{B}$ 과 $Y_{t-i}^{S}$ 를 구 하는 방법과 동일한 방식으로 도출하여 아래 식 (12)와 같이 동태적 사후분석을 실시하였다.

$$
\begin{aligned}
Y_{t-(i-1)}^{S}-Y_{t-(i-1)}^{B} & =Y_{t-(i-1)}^{\widehat{S}}+\widehat{U_{t-(i-1)}^{\widehat{S}}}-\widehat{Y_{t-(i-1)}^{\widehat{B}}}-U_{t-(i-1)}^{\widehat{B}} \\
& =Y_{t-(i-1)}^{\widehat{S}}-Y_{t-(i-1)}^{\widehat{B}} \\
Y_{t-(i-2)}^{S}-Y_{t-(i-2)}^{B} & =Y_{t-(i-2)}^{\widehat{S}}+\widehat{U_{t-(i-2)}}-Y_{t-(i-2)}-\widehat{U_{t-(i-2)}} \\
& =Y_{t-(i-2)}^{\widehat{S}}-\widehat{Y_{t-(i-2)}}
\end{aligned}
$$$$
Y_{t}^{S}-Y_{t}^{B}=\widehat{Y_{t}^{S}}+\widehat{U_{t}^{S}}-\widehat{Y_{t}^{B}}-\widehat{U_{t}^{B}}=\widehat{Y_{t}^{S}}-\widehat{Y_{t}^{B}}
$$

\section{4. 연구결과}

\section{1. 모형 추정결과}

분석모형은 지역별 재배면적과 단수, 가격연결식의 11 개 연 간변수 행태방정식 그리고 월말재고량, 수입량, 소비량을 나타 내는 36 개의 월간변수 행태방정식, 월초재고량을 나타내는 12 
개 항등식, 각월별 시장균형조건을 나타내는 12 개의 항등식 등으로 구성되어 있다. 본 연구는 모형 내의 개별 행태방정식 들을 OLS를 이용하여 추정하였다. 일부 월말재고함수와 소비 함수의 경우 전체 모수들을 회귀분석을 통하여 추정하는 일반 적인 방법이 아닌, 시장 상황과 경제 이론에 바탕하여 가정된 탄성치들에 입각해 함수식 내의 특정 변수의 추정치를 구하고, 이를 제약조건으로 두고 회귀분석을 실시하여 나머지 변수들 의 추정치를 도출하는 합성적(synthetic) 방법으로 구하였다.

방정식 추정 결과 모든 추정치가 경제학적 이론과 건고추 산업의 현실에 부합한 것으로 나타났고 $90 \%$ 유의계수 안에서 통계적으로 유의하였다. 또한 모든 행태방정식들이 자기상관이 없는 것으로 나타났다.

본 절에서는 지면의 제약으로 전체 행태방정식에 대한 추정 결과가 아닌 주요 내생변수의 추정결과만을 제시한다. 추정된 함수들의 결과 값을 나타내는 표는 추정된 독립변수의 계수값, 유의성을 검정하기 위한 P-value값, 모형 적합도를 나타내는 $R^{2}$ 값과 자기상관의 여부를 판단하는 BG-LM P-value 값으로 구성되어 있다. 많은 경우 모형의 유의성을 확보하기 위해 적 절한 더미변수를 포함하였지만 지면의 제약으로 더미변수의 추정결과는 생략하였다.

\subsection{1. 재배면적 함수 추정결과}

전남지역 재배면적 추정 결과 건고추의 전기재배면적과 전 기 순수익과는 양(+)의 상관관계에 있으며, 대체작목인 콩의 순수익과는 음(-)의 상관관계에 있을 것이라는 경제학적 기준 에 부합하게 도출이 되었다.

$<$ Table 1> Chonnam Area Estimation Result

\begin{tabular}{|c|c|c|}
\hline Variable & Estimate & P-Value \\
\hline Constant & 3394.21 & $0.031^{* *}$ \\
\hline$A C R_{t-1}$ & 0.27 & $0.014^{* *}$ \\
\hline$N E T R P_{t}$ & 337988.5 & $0.000^{* * *}$ \\
\hline NERTS $_{t}$ & -69203.6 & $0.007^{* * *}$ \\
\hline \multicolumn{3}{|c|}{$R^{2}=0.96$ BG-LM P-Value $=0.28$} \\
\hline
\end{tabular}

\subsection{2. 단수 함수 추정결과}

전남지역 단수 추정결과, 7 9월 평균기온이 올라가면 단수 가 증가하고, 7 9월 강수량과 일조시간이 증가하면 단수는 감 소하는 것으로 결과가 도출되었다.

<Table 2> Chonnam Yield Estimation Result

\begin{tabular}{|c|c|c|}
\hline Variable & Estimate & P-Value \\
\hline Constant & -214.61 & 0.304 \\
\hline$A V T E M P_{t}$ & 24.28 & $0.011^{* *}$ \\
\hline$R A I N_{t}$ & -0.13 & $0.031^{* *}$ \\
\hline$S U N_{t}$ & -0.49 & $0.067^{*}$ \\
\hline \multicolumn{2}{|c|}{$R^{2}=0.83$ BG-LM P-Value $=0.19$} \\
\hline
\end{tabular}

${ }^{* * *} p<0.01, \quad{ }^{* *} p<0.05,{ }^{*} p<0.1$

\subsection{3. 월말재고 함수}

9월 말 재고수요는 예상한 바와 같이 거래적 수요를 나타내 는 전월 재고량, 즉 9 월 초 재고량과 양(+)의 상관관계, 그리 고 투기적 수요를 반영한 실질 도매시장가격과는 음(-)의 상관 관계에 있는 것으로 추정되었다. 하지만 예방적 수요를 나타내 는 상수항은 통계적으로 유의하지 않은 것으로 나타났다.

<Table 3> September Ending Stock Estimation Result

\begin{tabular}{|c|c|c|}
\hline Variable & Estimate & P-Value \\
\hline Constant & 15944.91 & 0.276 \\
\hline$B T S_{t}^{s e p}$ & 0.95 & $0.000^{* * *}$ \\
\hline$\frac{W P_{t}^{e p}}{C P I_{t}^{s e p}}$ & -197.31 & $0.001^{* * *}$ \\
\hline \multicolumn{2}{|c|}{$R^{2}=0.97$ BG-LM P-Value $=0.16$} \\
${ }^{* * *} p<0.01, \quad{ }^{* *} p<0.05,{ }^{*} p<0.1$
\end{tabular}

\subsection{4. 수입 함수}

추정결과 수입수요는 예상한 바와 같이 전월 실질도매시장 가격과 양(+)의 상관관계에 있고, 전월 수입단가와 월초 재고 량과는 음(-)의 상관관계가 있는 것으로 나타났다.

< Table 4> September Import Demand Estimation Result

\begin{tabular}{|c|c|c|}
\hline Variable & Estimate & P-Value \\
\hline Constant & 7607.70 & $0.000^{* * *}$ \\
\hline$\frac{W P_{t}^{4 u g}}{C P I_{t}^{\text {Aug }}}$ & 10.3335 & $0.051^{*}$ \\
\hline$\frac{I M P_{t}^{\text {Aug }}}{C P I_{t}^{\text {Aug }}}$ & -175027.50 & $0.000^{* * *}$ \\
\hline$B S T_{t}^{\text {Sep }}$ & -0.012 & $0.061^{*}$ \\
\hline \multicolumn{2}{|c|}{$R^{2}=0.95$ BG-LM P-Value $=0.17$} \\
\hline
\end{tabular}

${ }^{* * *} p<0.01, \quad{ }^{* *} p<0.05,{ }^{*} p<0.1$

\subsection{5. 소비 함수}

도매단계소비함수의 실질도매시장가격 변수의 계수는 가정 된 탄성치를 이용한 합성적(synthetic) 방법으로 추정하였다. 가격 탄력성의 범위는 -0.55 에서 -1.12 로, 수확기에는 비교적 비탄력적인 가격탄력성, 저장기인 1 월부터 7 월까지는 좀 더 탄력적인 가격 탄력성을 가정하였다. 9월의 경우는 소비에 대 한 실질가격 탄성치가 -0.6 이라는 가정 하에 -108.57 의 계수 값을 도출하여 아래와 같이 합성적으로 추정하였다.

<Table 5> September Wholesale Demand Estimation Result

\begin{tabular}{|c|c|c|}
\hline Variable & Estimate & P-Value \\
\hline Constant & -9070.60 & 0.207 \\
\hline$\frac{W P_{t}^{S e p}}{C P I_{t}^{S e p}}$ & -108.57 & \\
\hline Trend & 1550.04 & $0.018^{* *}$ \\
\hline \multicolumn{2}{|c|}{$R^{2}=0.85$ BG-LM P-Value $=0.71$} \\
${ }^{* * *} p<0.01, \quad{ }^{* *} p<0.05,{ }^{*} p<0.1$
\end{tabular}




\subsection{6. 가격 연결식}

도매가격과 산지가격의 관계 그리고 생산자의 재배면적 결 정에 중요한 영향을 미치는 농가판매가격을 결정하는 가격연 결식의 추정결과, 도매시장가격과 산지가격은 같은 방향으로 움직이는 것으로 나타났다.

<Table 6> Price Linkage Estimation Result

\begin{tabular}{|c|c|c|}
\hline Variable & Estimate & P-Value \\
\hline Constant & 25.86 & $0.000^{* * *}$ \\
\hline$W P_{t}$ & 0.006 & $0.000^{* * *}$ \\
\hline \multicolumn{3}{|c|}{$R^{2}=0.91$ BG-LM P-Value $=0.57$} \\
\hline
\end{tabular}

\section{2. 기준전망치(Baseline) 시뮬레이션 결과}

본 연구에서는 2015년 실시된 정부 건고추 수매의 가격안 정화 효과의 순효과를 계측하기 위하여 시뮬레이션을 통하여 2015 연산연도(2015년 08월 2016년 07월)의 실제 건고추 시 장상황을 도출하였으며, 이는 시나리오 분석의 비교 대상이 되 는 기준전망치(Baseline) 역할을 한다. 정부수매가 이루어진 2015년의 실제 건고추 재배면적, 생산량, 수입량, 월초재고량, 월말재고량, 소비량 및 연간, 월간 도매시장가격은 다음과 같다.

\section{3. 사후분석 시나리오 시뮬레이션 결과}

정부 국내산 건고추 수매비축은 1993년 이전에 주로 추진되 다가 2012년부터 다시 재개되어 2012년 1933톤, 2013년 5800 톤, 2015년 총 7,000톤(10월 4,882톤, 11월 2,118톤)을 수매하 였다. 본 연구는 "2013년 5.27 농산물 유통구조개선 종합대책" 이후에 이루어진 정부수매 비축 중 그 규모가 가장 크고 가장 최근에 이루어진 2015년 건고추 정부수매의 가격안정화 효과 를 사후분석하기 위하여 시나리오를 다음과 같이 설정하였다.

시나리오: 2015년 정부수매물량인 7,000톤(10월 4,882톤, 11월 2,118톤)의 수매가 이루어지지 않음.

시나리오 분석 기간을 2015년에 한정하지 않고 정부수매가 있었던 2012년과 2013년을 포함하여 각각 해당해의 정부수매 가격안정화 효과를 비교분석 하는 것도 의의가 있으나 제한된 지면에서 분석 기간을 늘리고 분석 변수를 줄이기보다는 분석 기간을 특정 연산연도로 좁히고 분석 대상을 가격변동률뿐만 아니라 월간 총수요와 총공급의 모든 요소를 포함하여 자세히 설명하는 방법을 택하였다.
정부정책효과를 나타내는 시나리오 분석치와 기준전망치의 차이는 다음과 같다. <Table 8>에서 보는 바와 같이 10 월과 11월의 정부수매 여부는 이미 그 전에 결정된 2015 연산연도 재배면적과 단수 그리고 생산량에 영향을 미치지 않고 10 월부 터 7월까지의 재고량, 수입량, 소비량, 가격에 영향을 미친다.

시뮬레이션 결과, 먼저 10 월말 재고량은 정부수매가 없을 때를 가정하여 기준전망치 대비 $5.4 \%$ 감소하여 수요측면에서 의 감소가 나타났다. 그 영향으로 가격이 기준전망치 대비 $33.2 \%$ 수준 감소하였고, 소비량이 $27.0 \%$ 상승하는 것으로 나타 났다. 수입량의 경우 전기도매시장가격과 수입가격에 영향을 받 도록 설정되어 있어 10 월에는 변화가 없는 것으로 분석되었다.

다음으로 11 월말의 재고량은 64,130 톤으로 기준전망치 대 비 $10.6 \%$ 감소한 것으로 나타났는데 이는 순수한 11 월 수매 물량 감축분에 10 월 재고 감소에 따른 파급 효과가 추가된 결 과이다. 10월 재고 감소가 11월 시장에 미치는 누적효과를 반 영하지 못하는 비교정태분석의 경우, 11 월 정부수매가 없음을 가정한 시나리오 시뮬레이션 결과는 11 월 기준전망치 월말재 고량에서 2,118톤의 정부수매량을 단순히 차감한 69,592 톤으 로 기준전망치 대비 $3 \%$ 감소한 것으로 분석된다. 이와 같이 비교정태분석에 의존한 접근방법은 동태분석에 비하여 정부정 책효과를 과소 혹은 과대평가할 가능성이 크다.

한편 11월 수입량은 10월 도매시장가격 하락으로 인한 부 (-)의 영향이 10 월 말 재고량, 즉 11 월 초 이월 재고량 하락에 의한 정(+)의 요인보다 커 기준전망치 대비 $9.7 \%$ 하락하는 것 으로 나타났다. 11월 수입량과 11월초 재고량 하락으로 인한 공급량 감소는 11 월 말 재고량 감소로 인한 수요 감소효과를 경감시켜 기준전망치 대비 11 월 가격을 10 월에 비하여 비교적 소폭(-12.5\%) 하락시키고 $7.2 \%$ 의 소비를 증가시키는 것으로 분석되었다.

12월의 수입량은 12월초 재고량 하락에 따른 증가 요인보 다 11 월 도매시장가격 하락에 따른 감소 요인이 커 기준전망 치 대비 $0.4 \%$ 감소하였다. 수입량 감소와 12 월초 재고량 감소 에 따른 공급량 감소로 가격은 상승하게 되고, 이 가격 상승은 다시 소비를 $1.9 \%$ 감소시켰다. 12월말 재고수요의 경우 $11.5 \%$ 하락하는 것으로 분석되었는데 이는 가격상승의 영향 과 전월 재고감소의 영향이 반영된 결과이다. 최종적으로 12 월 가격은 기준전망치 대비 $2.7 \%$ 상승하였다.

1월부터 7월까지의 수입량은 전월 가격 상승과 월초재고량 하락으로 인하여 베이스라인 대비 $1.5 \%$ 내외의 상승을 보였 다. 이러한 수입량의 소폭 상승에도 불구하고 전월에서 이월된 월초 재고량 하락의 폭이 상대적으로 커서 기준전망치 대비 공급량이 감소하여 $3 \%$ 내외의 가격 상승을 가져오고 이는 다 시 12 월과 비슷한 폭의 월말재고와 소비의 감소를 가져왔다.

$<$ Table 7> Baseline Simulation Results

(Unit: ha, ton, won/600g)

\begin{tabular}{|c|c|c|c|c|c|c|c|c|c|c|c|c|c|}
\hline \multirow{2}{*}{\multicolumn{2}{|c|}{ Area }} & Aug & Sep & Oct & Nov & Dec & Jan & Feb & Mar & Apr & May & Jun & Jul \\
\hline & & \multicolumn{12}{|c|}{34,514} \\
\hline \multicolumn{2}{|c|}{ Production } & \multicolumn{12}{|c|}{97,697} \\
\hline \multicolumn{2}{|c|}{ Import } & 7,364 & 8,314 & 8,927 & 8,869 & 9,837 & 8,516 & 8,194 & 8,452 & 9,664 & 9,671 & 8,988 & 8,826 \\
\hline \multicolumn{2}{|c|}{ Beginning Stock } & 49,210 & 131,525 & 101,665 & 90,253 & 71,710 & 63,378 & 60,607 & 60,665 & 53,991 & 52,310 & 52,257 & 53,470 \\
\hline \multicolumn{2}{|c|}{ Ending Stock } & 131,525 & 101,665 & 90,253 & 71,710 & 63,378 & 60,607 & 60,665 & 53,991 & 52,310 & 52,257 & 53,470 & 57,143 \\
\hline \multicolumn{2}{|c|}{ Consumption } & 20,956 & 36,312 & 18,072 & 25,455 & 16,006 & 9,431 & 6,196 & 12,719 & 9,361 & 7,731 & 5,692 & 3,010 \\
\hline \multirow{2}{*}{$\begin{array}{l}\text { Whole } \\
\text { sale } \\
\text { price }\end{array}$} & Month & 8,202 & 8,330 & 8,212 & 8,098 & 7,999 & 7,808 & 7,800 & 7,735 & 7,383 & 7,120 & 7,100 & 6,890 \\
\hline & Year & \multicolumn{12}{|c|}{7,723} \\
\hline
\end{tabular}


$<$ Table 8> Effects of Eliminating Government Purchases on Dried Red Pepper Market

(Unit: ha, ton, won/600g)

\begin{tabular}{|c|c|c|c|c|c|c|c|c|c|c|c|c|c|}
\hline & & Aug & Sep & Oct & Nov & Dec & Jan & Feb & Mar & Apr & May & Jun & Jul \\
\hline \multicolumn{2}{|c|}{ Area } & \multicolumn{12}{|c|}{$\begin{array}{c}34,514 \\
(0.0)\end{array}$} \\
\hline \multicolumn{2}{|c|}{ Production } & \multicolumn{12}{|c|}{$\begin{array}{c}97,697 \\
(0.0)\end{array}$} \\
\hline \multicolumn{2}{|c|}{ Import } & $\begin{array}{c}7,364 \\
(0.0)\end{array}$ & $\begin{array}{c}8,314 \\
(0.0)\end{array}$ & $\begin{array}{c}8,927 \\
(0.0)\end{array}$ & $\begin{array}{l}8,013 \\
(-9.7)\end{array}$ & $\begin{array}{l}9,800 \\
(-0.4)\end{array}$ & $\begin{array}{c}8,661 \\
(1.7)\end{array}$ & $\begin{array}{c}8,284 \\
(1.1)\end{array}$ & $\begin{array}{c}8,574 \\
(1.4)\end{array}$ & $\begin{array}{c}9,879 \\
(2.2)\end{array}$ & $\begin{array}{c}9,824 \\
(1.6)\end{array}$ & $\begin{array}{c}9,115 \\
(1.4)\end{array}$ & $\begin{array}{c}8,916 \\
(1.0)\end{array}$ \\
\hline \multicolumn{2}{|c|}{ Beginning Stock } & $\begin{array}{c}49,210 \\
(0.0)\end{array}$ & $\begin{array}{c}131,525 \\
(0.0)\end{array}$ & $\begin{array}{c}101,665 \\
(0.0)\end{array}$ & $\begin{array}{c}85,371 \\
(-5.4)\end{array}$ & $\begin{array}{l}64,130 \\
(-10.6)\end{array}$ & $\begin{array}{l}56,060 \\
(-11.5)\end{array}$ & $\begin{array}{l}53,742 \\
(-11.3)\end{array}$ & $\begin{array}{l}54,250 \\
(-10.6)\end{array}$ & $\begin{array}{l}47,943 \\
(-11.2)\end{array}$ & $\begin{array}{l}46,871 \\
(-10.4)\end{array}$ & $\begin{array}{c}47,271 \\
(-9.5)\end{array}$ & $\begin{array}{c}49,052 \\
(-8.3)\end{array}$ \\
\hline \multicolumn{2}{|c|}{ Ending Stock } & $\begin{array}{c}131,525 \\
(0.0)\end{array}$ & $\begin{array}{c}101,665 \\
(0.0)\end{array}$ & $\begin{array}{c}85,371 \\
(-5.4)\end{array}$ & $\begin{array}{l}64,130 \\
(-10.6)\end{array}$ & $\begin{array}{l}56,060 \\
(-11.5)\end{array}$ & $\begin{array}{l}53,742 \\
(-11.3)\end{array}$ & $\begin{array}{l}54,250 \\
(-10.6)\end{array}$ & $\begin{array}{l}47,943 \\
(-11.2)\end{array}$ & $\begin{array}{l}46,871 \\
(-10.4)\end{array}$ & $\begin{array}{c}47,271 \\
(-9.5)\end{array}$ & $\begin{array}{c}49,052 \\
(-8.3)\end{array}$ & $\begin{array}{c}53,222 \\
(-6.9)\end{array}$ \\
\hline \multicolumn{2}{|c|}{ Consumption } & $\begin{array}{c}20,956 \\
(0.0)\end{array}$ & $\begin{array}{c}36,312 \\
(0.0)\end{array}$ & $\begin{array}{c}22,954 \\
(27.0)\end{array}$ & $\begin{array}{c}27,296 \\
(7.2)\end{array}$ & $\begin{array}{c}15,707 \\
(-1.9)\end{array}$ & $\begin{array}{l}9,123 \\
(-3.3)\end{array}$ & $\begin{array}{l}5,835 \\
(-5.8)\end{array}$ & $\begin{array}{c}12,473 \\
(-1.9)\end{array}$ & $\begin{array}{l}8,968 \\
(-4.2)\end{array}$ & $\begin{array}{l}7,431 \\
(-3.9)\end{array}$ & $\begin{array}{l}5,252 \\
(-7.7)\end{array}$ & $\begin{array}{c}2,603 \\
(-13.5)\end{array}$ \\
\hline \multirow{2}{*}{$\begin{array}{c}\text { Whole } \\
\text { sale } \\
\text { price }\end{array}$} & Month & $\begin{array}{c}8,202 \\
(0.0)\end{array}$ & $\begin{array}{c}8,330 \\
(0.0)\end{array}$ & $\begin{array}{c}5,484 \\
(-33.2)\end{array}$ & $\begin{array}{c}7,086 \\
(-12.5)\end{array}$ & $\begin{array}{c}8,211 \\
(2.7)\end{array}$ & $\begin{array}{c}8,045 \\
(3.0)\end{array}$ & $\begin{array}{c}8,048 \\
(3.2)\end{array}$ & $\begin{array}{c}7,911 \\
(2.3)\end{array}$ & $\begin{array}{c}7,599 \\
(2.9)\end{array}$ & $\begin{array}{c}7,364 \\
(3.4)\end{array}$ & $\begin{array}{c}7,353 \\
(3.6)\end{array}$ & $\begin{array}{c}7,157 \\
(3.9)\end{array}$ \\
\hline & Year & \multicolumn{12}{|c|}{$\begin{array}{l}7,566 \\
(-2.0)\end{array}$} \\
\hline
\end{tabular}

Note: Figures in parentheses are percentage differences between scenario and baseline.

월간도매가격의 평균값을 통하여 얻어진 2015 연산연도 평 균도매가격은 베이스라인대비 $2.0 \%$ 하락한 것으로 분석되었다. 이러한 비교적 소폭의 하락은 정부 수매가 없음을 가정한 10 월, 11 월 도매가격이 실제 가격에 비하여 각각 $33.2 \%, 12.5 \%$ 하락하여 단기적으로는 하락폭이 크지만, 2015 연산연도 전체 로 봤을 때 8,9 월 가격변화가 없고, 12 월부터는 공급 감소로 인한 지속적인 가격 상승이 중장기적으로 단기 가격 하락 영 향을 상쇄했기 때문이다.

본 연구는 정부수매가 건고추 가격 자체에 미치는 영향에 더하여 가격 변동률에 미치는 영향을 시나리오 분석결과에 바 탕하여 살펴보았다. <Table 9>는 정부 수매가 있었던 2015 연 산연도 건고추 실제 도매가격 변동률과, 정부 수매가 없음을 가정한 시나리오 분석결과의 가격 변동률을 정리한 것이다. 가 격 변동률은 전월대비 가격 상승 혹은 하락에 상관없이 변화 의 폭을 측정하기 위하여 매월 변동률에 절대값을 취하여 2015 연산연도 평균 가격 변동률을 구하였다.

정부개입, 즉 건고추 수매가 있을 때의 2015 연산연도 실제 평균 전월대비 가격변동률은 $1.7 \%$ 였고, 시나리오 분석결과 건 고추 수매가 없었다고 가정했을 때의 가격변동률은 $7.9 \%$ 로 나 타나 정부개입(수매)이 없었을 때 가격변동성이 더 크게 나타 남을 알 수 있었다. 또한 변이계수의 경우 정부개입(수매) 시 0.06 , 정부개입(수매)이 없을 시 0.10 으로 나타나 정부개입(수 매)이 건고추 가격안정에 효과가 있다고 평가할 수 있다.
<Table 9> Monthly Wholesale Price Variation Rate Compared to Last Month in 2015

\begin{tabular}{|c|c|c|c|c|}
\hline \multirow{2}{*}{} & \multicolumn{2}{|c|}{$\begin{array}{c}\text { With Government } \\
\text { Intervention } \\
\text { (With Government } \\
\text { Purchases) }\end{array}$} & \multicolumn{2}{c|}{$\begin{array}{c}\text { Without Government } \\
\text { Intervention } \\
\text { (Assuming Without } \\
\text { Government Purchases) }\end{array}$} \\
\cline { 2 - 5 } & Price(won) & $\begin{array}{c}\text { Variation } \\
\text { Rate(\%) }\end{array}$ & Price(won) & $\begin{array}{c}\text { Variation } \\
\text { Rate(\%) }\end{array}$ \\
\hline Aug & 8,202 & $0.0 \%$ & 8,202 & $0.0 \%$ \\
\hline Sep & 8,330 & $1.6 \%$ & 8,330 & $1.6 \%$ \\
\hline Oct & 8,212 & $1.4 \%$ & 5,484 & $34.2 \%$ \\
\hline Nov & 8,098 & $1.4 \%$ & 7,086 & $29.2 \%$ \\
\hline Dec & 7,999 & $1.2 \%$ & 8,211 & $15.9 \%$ \\
\hline Jan & 7,808 & $2.4 \%$ & 8,045 & $2.0 \%$ \\
\hline Feb & 7,800 & $0.1 \%$ & 8,048 & $0.0 \%$ \\
\hline Mar & 7,735 & $0.8 \%$ & 7,911 & $1.7 \%$ \\
\hline Apr & 7,383 & $4.5 \%$ & 7,599 & $4.0 \%$ \\
\hline May & 7,120 & $3.6 \%$ & 7,364 & $3.1 \%$ \\
\hline Jun & 7,100 & $0.3 \%$ & 7,353 & $0.1 \%$ \\
\hline Jul & 6,890 & $2.9 \%$ & 7,157 & $2.7 \%$ \\
\hline Average & 7,723 & $1.7 \%$ & 7,566 & $7.9 \%$ \\
\hline Coefficient of & & & \multicolumn{2}{|c}{0.10} \\
\hline Variation & & & & \\
\hline & & & & \\
\hline
\end{tabular}




\section{5. 결론 및 시사점}

\section{1. 연구결과의 요약}

농산물 가격 불안정성은 농가소득과 소비자 물가의 불안요 소로서 농업정책당국은 농산물가격 변동성을 완화하기 위하여 가격 변동성이 큰 5 대 노지채소를 중심으로 계약재배, 국내산 수매비축 확대 등의 다양한 정책을 실시하고 있다.

이러한 수급체계화 정책의 성과에 대한 정부의 평가는 정책 실시 전·후의 월평균 전월대비 가격변동률을 통해서 이루어지 고 있다. 하지만 이러한 접근방법은 전체 가격변동률에서 순수 한 정부정책 효과를 구분하지 못한다는 한계점을 가지고 있다.

본 연구는 가격 변화가 심한 5대 노지채소 중 하나인 건고 추를 대상으로, 2015년 정부 건고추 수매가 2015년 건고추 시 장 가격안정화에 미친 순효과(net effect)를 월간동태부분균형 모형을 바탕으로 사후분석(ex-post analysis)을 통하여 검증하 였다.

사후분석은 2015 연산연도 7,000톤(10월 4,882톤, 11월 2,118 톤)의 건고추 정부수매가 이루어지지 않았을 때의 시나 리오를 가정하여 진행하였다. 분석결과에 의하면, 정부수매가 없음을 가정한 2015년 10월과 11월 가상의 건고추 도매가격 은 실제 정부수매가 있었던 현실의 도매가격에 비하여 각각 $33.2 \%, 12.5 \%$ 가 하락하여 2015년에 있었던 정부수매의 가격 상승효과가 단기적으로 작지 않은 것으로 분석되었다.

또한 2015 연산연도 건고추 평균 가격변동률을 통하여 살 펴본 정부수매의 중장기적 효과는 수매가 있었던 2015 연산연 도 실제 평균 전월대비 가격변화율은 $1.7 \%$, 정부개입(수매)이 없을 때를 가정한 시나리오 시뮬레이션을 통해 얻은 가상의 가격변화율이 $7.9 \%$ 로 나타나 정부개입이 없었을 때 가격변동 성이 비교적 더 큰 것으로 나타났다. 또한 변이계수의 경우 정 부개입(수매)시 0.06 , 정부개입(수매)이 없을 시 0.10 으로 나타 나 역시 정부의 건고추 수매비축이 건고추의 가격안정에 효과 가 있다고 판단할 수 있다.

\section{2. 연구의 시사점}

본 연구는 농산물 가격 변동성 그리고 채소부분 정부정책 효과분석과 관련된 기존 선행연구의 한계점을 보완할 수 있는 월간동태부분균형모형 개발을 통해, 정부 수매 비축 등 건고추 시장과 관련된 다양한 정책에 대한 사전·사후 단기 동태 분석 이 가능하도록 하였다는 데 의의가 있다.

또한, 본 연구의 분석 결과는 정부의 시장개입에 대한 타당 성을 부여하였다는 점에서 그 시사점을 찾을 수 있다. 비탄력 적인 공급과 수요에서 기인한 농산물 가격의 급등락과 그로인 한 높은 가격 변동성은 농산물 시장에 대한 정부개입의 근거 로 이용된다. 보다 구체적으로 정부수매의 예를 들어 정부개입 의 당위성을 설명하면, 정부수매는 단기적으로는 공급과잉으로 시장가격 폭락이 예상되는 상황에서 정부수요를 증가시켜 가 격 하락을 막고 중장기적으로는 가격 변동성을 완화하여 농업 소득과 소비자물가를 안정시킨다.

그러나 정부의 다양한 형태의 시장개입에도 불구하고 반복 적으로 재현되는 농산물가격의 불안정성은 정부 수급안정화 정책에 대한 불신으로 작용되고 있고, 정책의 방향을 시장에 직접 개입하여 가격 안정화를 꽤하는 수급정책보다는 수급조
절 기능을 시장에 맡기고 농민의 소득을 보장해주는 소득정책 으로의 전환해야 한다는 주장의 논거로 이용되고 있다.

이러한 정부정책에 대한 불신과 정책방향의 전환에 대한 논 의가 있는 상황에서 정부개입의 가격안정화에 대한 효과를 실 증적으로 검증한 본 연구는 향후 농산물 유통개선대책 방향 제시에 유용한 정보로 이용될 수 있을 것이다.

\section{3. 연구의 한계점 및 향후 연구방향}

본 연구는 건고추 농가의 생산결정에서부터 유통업자, 수입 업자, 도매업자, 정책당국자의 의사결정과정을 모형화하여 외 부환경변화에 시장참여자들의 반응과 그로 인한 단기에서의 시장 변동과정을 분석 가능하도록 하였다. 그러나 본 연구는 자료의 한계로 인하여 소비자 수요를 모형 내에 포함하지 못 하였다. 이러한 이유로, 정부 정책 등 외부환경 변화가 소비자 구매 패턴에 미치는 영향 더 나아가서 건고추 시장에서 소비 자 의사결정의 변화가 도매 및 산지시장에 미치는 영향을 분 석하는데 한계점이 있다.

또한, 본 연구는 건고추 시장에만 한정된 연구로서 정부가 5 대 채소로 지정하여 유사한 수급체계화 정책을 펼치고 있는 배추, 무, 마늘, 양파 시장을 포함한 채소 시장에 대한 종합적 인 정책 분석이 어렵다는 제약점이 있다. 이러한 한계점들의 보완은 향후 연구 과제로 남기고자 한다.

\section{References}

Hoang, H. J., \& Meyers, W. H. (2015). Price stabilization and impacts of trade liberalization in the Southeast Asi an rice market. Food Policy, 57(November), 26-39.

Hong, H. (2016). Information Cascade and Share Market Volatility: A Chinese Perspective. Journal of Asian Fina nce, Economics and Business, 3(4), 17-24.

Huang, S. W., \& Huang, K. S. (2012). Marketing Effects of U.S. Fresh Produce Imports. Journal of Agribusines $s, 30(1), 53-67$.

Jati, K., \& Premaratne, G. (2017). Analysis of Staple Foo d Price Behaviour: Multivariate BEKK-GARCH Model. J ournal of Asian Finance, Economics and Business, 4( 4), 27-37.

Jin, H. J., \& Kim, T. H. (2012). Structural Changes in the Time Series of Food Prices and Volatility Measurement. American Journal of Agricultural Economics, 94(4), 929944.

Karali, B., \& Power, G. J. (2013). Short- and Long-run Determinants of Commodity Price Volatility. American $J$ ournal of Agricultural Economics, 95(3), 724-738.

Key, N., Prager, D. L., \& Burns, C. B. (2018). The Incom e Volatility of U.S. Commercial Farm Households. Appli ed Economic Perspectives and Policy, 40(2), 215-239.

Kim, S. S. (2013). A Study on the Impact of Oil Price Vo latility on Korean Macro Economic Activities: An EGAR $\mathrm{CH}$ and VECM Approach. Journal of Distribution Scienc $e$, 11(10), 73-79. 
Kim, Y. C., \& Yi, M. H. (2016). A Study on the Sudden Stop in Capital Flows and Foreign Exchange and Distri bution Market Stability. Journal of Distribution Science, 14(12), 79-87.

Lama, A., Jha, G. K., Paul, R. K., \& Gurung, B. (2015). Modelling and Forecasting of Price Volatility: An Applic ation of $\mathrm{GARCH}$ and $\mathrm{EGARCH}$ Models. Agricultural EC onomics Research Review, 28(1), 73-82.

Lee, J. W., \& Brahmasrene, T. (2018). An Exploration of Dynamical Relationships between Macroeconomic Varia bles and Stock Prices in Korea. Journal of Asian Finan ce, Economics and Business, 5(3), 7-17.

Lee, J. W., \& Zhao, T. F. (2014). Dynamic Relationship b etween Stock Prices and Exchange Rates: Evidence $\mathrm{fr}$ om Chinese Stock Markets. Journal of Asian Finance, Economics and Business, 1(1), 5-14.

Mcphail, L. L., \& Babcock, B. A. (2012). Impact of US bi ofuel policy on US corn and gasoline price variability. Energy, 37(1), 505-513.

Meyers, W. H., Westhoff, P., Fabiosa, J. F., \& Hayes, D. J. (2010). The FAPRI Global Modeling System and Out look Process. Journal of International Agricultural Trade and Development, 6(1), 1-19.

Rahmi, M., Azma, N., Muttaqin, A. A., Jazil, T., \& Rahma n, M. (2016) Risk Volatility Measurement: Evidence fro $\mathrm{m}$ Indonesian Stock Market, Journal of Asian Finance, Economics and Business, 3(3), 57-65.

Saghaian, S., Nemati, M., Walters, C., \& Chen, B. (201 8). Asymmetric Price Volatility Transmission between U.
S. Biofuel, Corn, and Oil Markets. Journal of Agricultur al and Resource Economics, 43(1), 46-60.

Sahadudheen, I. (2015). An Exponential GARCH Approac $\mathrm{h}$ to the Effect of Impulsiveness of Euro on Indian Sto ck Market. Journal of Asian Finance, Economics and $B$ usiness, 2(3), 17-22.

Siddiqui, M. A., \& Erum, N. (2016). Modeling Effect of Ex change Rate Volatility on Growth of Trade Volume in $\mathrm{P}$ akistan. Journal of Asian Finance, Economics and Busi ness, 3(2), 33-39.

Su, Y., \& Cook, M. L. (2015). Price Stability and Economic Substantiality-Achievable Goals? A Case Study of Organic Valley. American Journal of Agricultural Economics, 97(2), 635-651.

Thompson, W., Gerlt, S., Campbell, J. E., Kueppers, L. M., Lu, Y., \& Snyder, M. A. (2017). A Cost of Tractabil ity? Estimating Climate Change Impacts Using a Single Crop Market Understates Impacts on Market Conditions and Variability. Applied Economic Perspectives and Poli cy, 39(2), 346-362.

Thompson, W., Johansson, R., Meyer, S., \& Whistance, J. (2018). The US biofuel mandate as a substitute for carbon cap-and-trade. Energy Policy, 113(February), 36 8-375.

Trujillo-Barrera, A., Mallory, M., \& Garcia, P. (2012). Volat ility Spillovers in U.S. Crude Oil, Ethanol, and Corn Fut ures Markets. Journal of Agricultural and Resource Eco nomics, 37(2), 247-262. 